Original Research Article

\title{
Molecular mechanisms responsible for programmed cell death- inducing attributes of terpenes from Mesua ferrea stem bark towards human colorectal carcinoma HCT 116 cells
}

\author{
Muhammad Asifa,*, Majed Ahmed Al-Mansoub ${ }^{\mathrm{b}}$, MD Shamsuddin Sultan Khan ${ }^{\mathrm{a}}$, \\ Ashwaq Hamid Salem Yehya ${ }^{c}$, Mohammed Oday Ezzat ${ }^{\mathrm{d}}$, Chern Ein Oon ${ }^{\mathrm{c}}$, \\ Muhammad Atif ${ }^{\mathrm{e}}$, Aman Shah Abdul Majid ${ }^{\mathrm{f}}$, Amin Malik Shah Abdul Majid ${ }^{\mathrm{a}, \mathrm{g}, * *}$ \\ a EMAN Testing and Research laboratory, Department of Pharmacology, School of Pharmaceutical Sciences, Universti Sains Malaysia, Penang 11800, Malaysia \\ b Department of Pharmacology, School of Pharmaceutical Sciences, Universti Sains Malaysia, Penang 11800, Malaysia \\ ${ }^{\mathrm{c}}$ Institute for Research in Molecular Medicine (INFORMM), Universti Sains Malaysia, Penang, 11800, Malaysia \\ d Centre for Drug Research, Universti Sains Malaysia, Penang, 11800, Malaysia \\ e Department of Pharmacy, The Islamia University of Bahawalpur, 63100, Punjab, Pakistan \\ ${ }^{\mathrm{f}}$ Advanced Medical and Dental Institute, Universti Sains Malaysia, Penang 13200, Malaysia \\ ${ }^{g}$ ACRF Department of Cancer Biology and Therapeutics, The John Curtin School of Medical Research, Australian National University, Australia
}

\section{A R T I C L E I N F O}

\section{Article history:}

Received 1 November 2015

Received in revised form 30 September 2016

Accepted 6 October 2016

Available online 18 October 2016

\section{Keywords:}

Mesua ferrea

Terpenes

Programmed cell death

ROS

Signalling pathways

\section{A B S T R A C T}

The current study explored the in vitro anticancer properties of Mesua ferrea stem bark (SB) extract towards human colon carcinoma HCT116 cells. SB was successively extracted with different solvents using soxhlet apparatus. MTT assay was employed to test toxicity against different cancer and normal cell lines. Active extract ( $n$-Hexane) was fractionated by column chromatography (CC) to get the most active fraction (F-3). Series of in vitro assays were employed to characterize cytotoxic nature of F-3. Antioxidant properties of F-3 were assessed using DPPH, ABTS and FRAP assays followed by GC-MS analysis. Intracellular ROS levels were measured by DCFH-DA fluorescent assay. Finally, cell signalling pathways and their downstream proteins targeted by F-3 were studied using 10-cancer pathway and human apoptosis protein profilers and in silico docking studies. $n$-Hexane extract and its fraction (F-3) showed potent anti-proliferative effect against HCT 116. Programmed cell death (PCD) studies showed that F-3 modulated the expression of multiple proteins in HCT 116. F-3 showed weak antioxidant activity in all the models, while significant increase in ROS was observed in HCT 116. GC-MS analysis revealed that F-3 was majorly comprised of terpenes. Data of pathway profiler and in silico studies revealed that F-3 downregulated the expression of NF- $\mathrm{KB}$ and HIF-1 $\alpha$ pathways. Overall these results demonstrate that anticancer effects of $M$. ferrea stem bark towards human colon carcinoma are mainly due to its terpenes contents.

(c) 2016 Faculty of Health and Social Sciences, University of South Bohemia in Ceske Budejovice. Published by Elsevier Sp. z o.o. All rights reserved.

\footnotetext{
* Corresponding author.

** Corresponding author.

E-mail addresses: asif_pharmacist45@yahoo.com (M. Asif), madjed_25@yahoo.fr (M.A. Al-Mansoub), Jupitex@gmail.com (M.S.S. Khan), ashwaqlabwork@gmail.com (A.H.S. Yehya), mohamed_oday@yahoo.com (M.O. Ezzat), chern.oon@usm.my (C.E. Oon),pharmacist_atif@yahoo.com (M. Atif), amanshah75@gmail.com (A.S. Abdul Majid), Aminmalikshah@gmail.com (A.M.S. Abdul Majid).
}

\section{Introduction}

Cancer is a life threatening condition involving aberrant expression of multiple cell signalling pathways. In spite of the tremendous efforts, anticancer drug development has been greatly hampered by the limited sources of chemical scaffolds. Moreover, majority of conventional chemotherapeutic agents used today were designed to hit a single intracellular target, making them merely ineffective in advance stages of cancers, where multiple cellular events support the continuous growth of tumors (Anighoro et al., 2014). Therefore, multi-targeted 
approach in which an agent can target multiple cellular events at the same time is now extensively explored for the treatment of cancer (Lu et al., 2012). Natural products either in form of single isolated compound or mixture of compounds with different chemical structures, have been reported to act synergistically to target multiple oncogenic pathways and are associated with tolerable or even no toxicity at therapeutic doses (Amin et al., 2009; Asif et al., 2016a). Moreover, several epidemiological studies have reported an inverse correlation between a high intake of natural products and reduced risk of cancer including colorectal cancer (CRC) (Tan et al., 2011). The importance of natural products as anticancer agents is also reflected by the fact that a variety of chemotherapeutic drugs (vincristine, irinotecan, etoposide, and paclitaxel) in practice today were derived from natural sources (Huang et al., 2012). Therefore, development and isolation of novel compounds from natural sources has become an important part of cancer research.

Reduced rate of programmed cell death (PCD) in tumor cells is one of the key features of carcinogenesis which usually results from imbalance between pro- and anti-apoptotic proteins (Wong, 2011). Similarly, an inverse relationship between ROS levels and expression of apoptotic machinery (Bcl-2 family proteins, survivin, XIAP and other pro-survival proteins) has also been established, which points towards the importance of ROS-targeted therapies in the treatment of cancer (Hildeman et al., 2003; Jia et al., 2015). Several preclinical studies have reported that resistance to chemotherapy-induced cell death in cancer cells including CRC is linked with irregular expression of hypoxia inducible factor- $1 \alpha$ $(\mathrm{HIF}-1 \alpha)$ and nuclear factor- $\mathrm{kb}(\mathrm{NF}-\kappa \mathrm{B})$ cell signalling pathways. A large number of natural products including pentacyclic triterpenes i.e., betulinc acid and urosolic acid are reported to regulate these signalling pathways via up-regulation of ROS (Ioannou et al., 2015; Hassanzadeh, 2011; Juan et al., 2008; Fulda, 2008; Prasad et al., 2011). Therefore, one of the most rational approaches suggested to arrest tumorigenesis is simultaneous targeting of multiple cell signalling pathways in the cancer cells.

Mesua ferrea (Penaga lilin) is an ornamental plant of family guttiferae which is extensively studied for its anticancer activities in Asian countries including Malaysia. In vitro anticancer activities of $M$. ferrea against a variety of cancer cell lines i.e., MCF-7, KB, NCI-H187, NCI-H23, Raji, SNU-1, K562, LS-174T, HeLa, SK-MEL-28, IMR-32, Hep-G2, HT-29 and LIM1215 have already been reported (Mahavorasirikul et al., 2010; Teh et al., 2011, 2013; Sukanya and Samart, 2012; Asif et al., 2016b). However, to best of our knowledge, there is no detailed study available that reports the molecular mechanisms responsible for the anticancer effects of $M$. ferrea stem bark extract against HCT 116 (human colorectal carcinoma) cell line. Therefore, present study was undertaken to assess the in vitro anticancer effects of $M$. ferrea stem bark against a panel of human cancer cell lines. The National Cancer Institute (NCI) criterion, that a plant extract with an $\mathrm{IC}_{50} \leq 20 \mu \mathrm{g} / \mathrm{mL}$ is considered cytotoxic, was used to select the cytotoxic extract as well as the most sensitive cancer cell line for further detailed study (Abdel-Hameed et al., 2012).

\section{Experimental}

\section{Collection of plant material}

Flowers, leaves and stem bark (SB) of $M$. ferrea were collected from the trees located in the Universiti Sains Malaysia (USM), premises. After identification by a botanist, Dr. Rahmad Zakaria, the plant sample was submitted at the herbarium, School of Biological Sciences, for the future reference (voucher number 11535).

\section{Extraction and bioactivity guided fractionation}

Collected parts (flowers, leaves and stem bark) were washed with water to remove debris and dried in a hot air oven set at $40^{\circ} \mathrm{C}$. Subsequently, each part was individually crushed into a coarse powder using an electric grinder. For screening purpose, approximately $500 \mathrm{~g}$ powder of each plant part was extracted with $2 \mathrm{~L}$ of methanol at $40^{\circ} \mathrm{C}$ for $48 \mathrm{~h}$, in air tight containers with continuous shaking. The soaked material was then filtered using a filter paper, and filtrates were evaporated using a rotary evaporator to form a thick, viscous mass. The crude extracts of flowers, leaves and SB were labelled as MF.Cr, ML.Cr and MB.Cr respectively. The stock solution $(20 \mathrm{mg} / \mathrm{mL})$ of crude extracts was prepared in dimethyl sulfoxide (DMSO) for in vitro anticancer screening against HCT 116 cells. Based on MTT assay screening results, SB was selected for detailed phytopharmacological experimentation. Approximately, $5 \mathrm{~kg}$ of SB was successively extracted with solvents of increasing polarities [ $n$-hexane ( $n$-Hex), chloroform (CF), ethyl acetate (EA) and methanol (ME)] using soxhlet extraction apparatus set at $40^{\circ} \mathrm{C}$. All the resultant extracts were again screened for in vitro anticancer activity against HCT 116 cells. Fractionation of $n$-Hex extract was carried out by column chromatography (CC) technique using solvents of increasing polarities ( $n$-Hex with $\mathrm{CF}$ ( $2 \%$ increase), $50 \& 100 \%$ EA and $50 \& 100 \% \mathrm{ME}$ ). Based on thin layer chromatography (TLC) results, similar fractions were pooled. All the resultant fractions were checked for cytotoxicity against HCT 116 cells, which resulted in the assortment of fraction-3 (F-3) as one of the most potent cytotoxic fractions (Asif et al., 2015; Keawsa-ard et al., 2015).

Chemical characterization by gas chromatography mass spectrometer (GC-MS)

An Agilent GC-MS coupled with electrospray ionization was used for the detailed chemical characterization of F-3 following a well-established method (Asif et al., 2016a). Mass spectral correlations were performed using the NIST02 database.

\section{Antioxidant assays}

Antioxidant capacities of F-3 were assessed using 2,2 diphenyl1-picrylhydrazyl (DPPH), 2,2'-azino-bis(3-ethylbenzothiazoline-6sulphonic acid) (ABTS) and ferric reducing antioxidant power (FRAP) assays following well-established protocols (Asif et al., 2016a). For DPPH assay, six different concentrations of F-3 (100$3.125 \mu \mathrm{g} / \mathrm{mL})$ were prepared from the stock solution $(10 \mathrm{mg} / \mathrm{mL})$ using a twofold serial dilution method. While for ABTS assay, the concentrations selected were in the range of $40-1.25 \mu \mathrm{g} / \mathrm{mL}$ respectively.

\section{DPPH assay}

In brief, $100 \mu \mathrm{L}$ of each dilution of ascorbic acid/F-3 and DPPH ( $200 \mu \mathrm{mol} \mathrm{L}^{-1}$ in methanol) reagent was added into each well of a 96-well plate (in triplicate) followed by incubation at room temperature for $30 \mathrm{~min}$ in the dark. Subsequently, absorbance of remaining DPPH was measured at $517 \mathrm{~nm}$ and the results are expressed as $\mathrm{IC}_{50}$ i.e., concentration required to inhibit formation of DPPH radicals by $50 \%$. Ascorbic acid was used as a reference standard $(n=3)$.

\section{ABTS assay}

A total $200 \mu \mathrm{L}$ of reaction mixture containing $180 \mu \mathrm{L}$ of ABTS working solution and $20 \mu \mathrm{L}$ of each dilution of ascorbic acid/F-3 was added in each well of a 96 -well plate separately (in triplicate). 
Plate was incubated for $6 \mathrm{~min}$ at room temperature and the absorbance of reaction mixture was measured at $734 \mathrm{~nm}$. The results are expressed as $\mathrm{IC}_{50}$ values and compared with the $\mathrm{IC}_{50}$ value of ascorbic acid $(n=3)$. Method of ABTS working solution preparation is mentioned in the Supplementary file.

\section{FRAP assay}

A $200 \mu \mathrm{L}$ of reaction mixture $(150 \mu \mathrm{L}$ of FRAP working solution and $50 \mu \mathrm{L}$ of $\mathrm{F}-3 ; 10 \mathrm{mg} / \mathrm{mL}$ stock solution) was added to each well of a 96-well plate (in triplicate). The absorbance of the reaction mixture was measured at $600 \mathrm{~nm}$ after $8 \mathrm{~min}$ of incubation. FRAP value of F-3 was calculated using linear regression equation $\left(\mathrm{R}^{2}\right)$ of ferrous sulphate $\left(\mathrm{FeSO}_{4} \cdot 7 \mathrm{H}_{2} \mathrm{O}\right)$ dose-response curve. Results are expressed as $\mu \mathrm{mol} \mathrm{Fe}+^{2}$ equivalent $\mu \mathrm{g}-1$ dry extract $(n=3)$. Method of FRAP working solution preparation is mentioned in the Supplementary file.

Measurement of intracellular reactive oxygen species (ROS) in HCT 116 cells

The effect of F-3 on the generation of reactive oxygen species (ROS) in HCT 116 cells were studied using a cell-permeable fluorescent dye i.e., $2^{\prime}$,7'-dichlorofluorescein diacetate (DCFH-DA) (100 mM in DMSO) following a reported method (Asif et al., 2016b). In brief, $10 \times 10^{4}$, HCT 116 cells/well were treated with three different concentrations of F-3 $(7,14$ and $28 \mu \mathrm{g} / \mathrm{mL})$ for $24 \mathrm{~h}$. Media containing $0.5 \%$ DMSO and $0.05 \%$ hydrogen peroxide $\left(\mathrm{H}_{2} \mathrm{O}_{2}\right)$ were used as negative and positive controls, respectively. The results are expressed as mean \pm SD of fluorescent intensity $(n=3)$.

\section{In vitro anticancer studies}

\section{MTT assay for measuring cell viability}

MTT (3-[4,5-dimethylthiazol-2-yl]-2,5 diphenyl tetrazolium bromide) assay was performed to screen the in vitro cytotoxic activity of $M$. ferrea stem bark extracts towards a panel of human cancer cell lines, viz. HCT 116 (colorectal carcinoma, ATCC ${ }^{\circledR}$ CCL-247), HT-29 (colorectal adenocarcinoma, ATCC ${ }^{\mathbb{R}}$ HTB-38), MCF-7 (mammary gland adenocarcinoma, ATCC ${ }^{\circledR}$ HTB-22), MDAMB-231 (mammary gland adenocarcinoma, ATCC ${ }^{\circledR}$ HTB-26), PANC-1 (pancreatic carcinoma, ATCC ${ }^{\circledR}$ CRL-1469), MIA PaCa-2 (pancreatic carcinoma, ATCC ${ }^{\circledR}$ CRL-1420), Capan-1(pancreatic ductal adenocarcinoma, ATCC ${ }^{\circledR}$ HTB-79), PC-3 (prostate cancer, ATCC $^{\circledR}$ CRL-1439) and MKN-74 (gastric adenocarcinoma, JCRB1473). CCD-18Co (normal human colon fibroblast, ATCC ${ }^{\circledR}$ CRL1459), 3T3-L1 (mouse fibroblast, ATCC ${ }^{\circledR}$ CL-173) and EA.hy926 (human endothelial cells, ATCC ${ }^{\circledR}$ CRL-2922) were used as normal cell lines. In brief, a total of 5000-10,000 overnight seeded cells/ well in a 96-well plate were treated with different concentrations (100-3.125 $\mu \mathrm{g} / \mathrm{mL}$ ) of test samples (MF.Cr, ML.Cr, MB.Cr, $n$-Hex, CF, EA, ME and F-3) for $48 \mathrm{~h} .5 \mu \mathrm{g} / \mathrm{mL}$ of 5-Fluorouracil (5-FU) and $0.5 \%$ DMSO in media were used as positive and negative controls, respectively. After $48 \mathrm{~h}, 20 \mu \mathrm{L}$ of MTT reagent ( $5 \mathrm{mg} / \mathrm{mL}$ in PBS) was added into each well and the plate was again incubated for additional $4 \mathrm{~h}$ in a cell culture incubator. Later, media was aspirated from each well carefully using a multichannel pipette. $100 \mu \mathrm{L}$ of DMSO was added into each well of a 96-well plate and the absorbance of dissolved formazan crystals was measured using a microplate reader (TECAN Infinite Pro ${ }^{\circledR}$ M200, Switzerland) at $570 \mathrm{~nm}$ as primary and $620 \mathrm{~nm}$ as reference wavelengths respectively. The results are presented as $\mathrm{IC}_{50}$ values (mean $\pm \mathrm{SD}$, $n=3$ ) (Asif et al., 2016c). Keeping in view the $\mathrm{IC}_{50}$ values of F-3 towards the most susceptible cell line i.e., HCT 116, three different concentrations $\left(\mathrm{IC}_{25}=7 \mu \mathrm{g} / \mathrm{mL}, \mathrm{IC}_{50}=14 \mu \mathrm{g} / \mathrm{mL}\right.$ and $\mathrm{IC}_{100}=28 \mu \mathrm{g} /$ $\mathrm{mL}$ ) of F-3 were selected for detailed mechanistic studies.

\section{Programmed cell death studies}

\section{Morphological observations}

Light microscopic observations were employed to study the typical morphological changes i.e., cell shrinkage, cell detachment from the surface of cell culture plate, membrane blebbing and echinoid spikes formation incurred in the most susceptible cells (HCT 116) as a result of exposure to F-3. In brief, $1 \times 10^{5}$,well overnight seeded cells in a 6 -well plate were treated with 7,14 and $28 \mu \mathrm{g} / \mathrm{mL}$ of F-3 for $48 \mathrm{~h}$. Later, the old media from the wells was aspirated and the cells were washed with PBS and fixed with $4 \%$ paraformaldehyde for $30 \mathrm{~min}$ at room temperature. Photos of five randomly selected fields per well were taken at $20 \times$ magnifications and morphological deformities were observed (Rahman et al., 2013).

\section{Hoechst 33258 and rhodamine 123 staining}

PCD-inducing effects of F-3 towards HCT 116 (cancerous) and CCD-18co (normal) cells were studied using two fluorescent cell organelle specific dyes i.e., Rhodamine 123 (red fluorescent, mitochondrial staining) and Hoechst 33258 (blue fluorescent, nuclear staining) respectively. In brief, HCT 116 and CCD-18co cells $\left(10 \times 10^{4} /\right.$ well $)$ were treated with 7,14 and $28 \mu \mathrm{g} / \mathrm{mL}$ of F-3, $5 \mu \mathrm{g} /$ $\mathrm{mL}$ of 5-FU (positive control) and 0.5\% DMSO (negative control) in media for $24 \mathrm{~h}$ respectively. Subsequently, cells were washed with PBS, fixed with $4 \%$ paraformaldehyde for $20 \mathrm{~min}$, and stained separately with Rhodamine $123(1 \mu \mathrm{g} / \mathrm{mL}$ in PBS) and Hoechst $33258(10 \mu \mathrm{g} / \mathrm{mL}$ in PBS) for $20 \mathrm{~min}$ in the dark. Afterwards, cells were washed twice with PBS and examined under red and blue filters of an inverted fluorescent microscope (EVOS $\mathrm{fl}$, Digital microscopy group, USA). Number of cells having PCD features i.e., having less red fluorescent signal (indicating the damage of mitochondrial membrane with subsequent loss of mitochondrial outer membrane potential) and more bright blue nucleus with altered morphology (indicating the damage of nuclear membrane and binding of Hoechst 33258 with A-T base pair) were counted in five randomly selected fields per well. The PCD index for each fluorescent stain was calculated and the results are presented as mean \pm SD $(n=3)$ (Asif et al., 2016c).

\section{Programmed cell death proteome profiler}

Human apoptosis antibody array (Raybiotech ${ }^{\circledR}$, USA) was used to study the effect of F-3 on the expression pattern of proteins (pro- and anti-apoptotic) involved in the PCD cascade following a well-established method (Asif et al., 2016b). HCT 116 cells in a 6 -well plate were treated with $\mathrm{IC}_{50}$ concentration $(14 \mu \mathrm{g} / \mathrm{mL})$ of F-3 for $24 \mathrm{~h}$. The array slide was scanned at Genomax ${ }^{\circledR}$ facility (Raybiotech $^{\circledR}$ supplier, Malaysia) using microarray scanner (Agilent G2505C, USA). Data obtained from scanning was exported into the analysis software and relative fold change in the expression pattern of each protein was calculated.

\section{Expression of major cancer signalling pathways in HCT116 cells}

To study the modulatory effects of F-3 on 10-major cancer pathways i.e., WNT, Notch, p53, NF- $\kappa B$, HIF- $1 \alpha$, TGF- $\beta$, cell cycle, Myc/Max, MAPK/ERK, and MAPK/JNK, the relative levels of

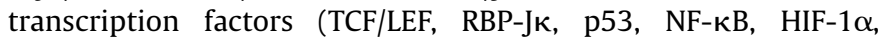
SMAD2/3/4, E2F/DP1, Myc/Max, Elk-1/SRF and AP-1) for these pathways were measured using multi-pathway array (SABiosciences, USA). The assay was performed in a 96-well plate format according to manufacturer's protocol. The result are presented as mean \pm SD of fold change in activity (relative to control cells) $(n=2)$. 
In silico docking studies of marker compound of F-3 ( $\alpha$-amyrin)

Molecular docking studies were performed using the AutoDock Vina 1.5.6 and Discovery studio client version 4.0 to analyse the docking. Proteins, $\alpha$-amyrin and betulinic acid structures were obtained from protein data bank and PubChem respectively. Detailed methodology is explained in Supplementary file (Trott and Olson, 2010).

\section{Statistical analysis}

The results are presented as mean \pm SD of three independent experiments. One-way ANOVA followed by post-hoc Tukey was performed at the significance level 2alpha $=0.05$ using GraphPad Prism (Graph PAD, San Diego, USA) software.

\section{Results}

Terpenes rich-fraction (F-3) showed most potent activity

Preliminary cytotoxic screening of crude extracts towards HCT 116 cells resulted in the selection of stem bark (SB) for further studies. Among different solvents extract of SB, non-polar extract ( $n$-hex extract) and its terpenes rich-fraction (F-3) were revealed to have potent cytotoxic activity towards HCT 116 cells (Table 1). Chemical characterization of F-3 by GC-MS resulted in the identification of total 22 compounds. 9 compounds with similarity 90 and above with NIST02 reference library, were considered for reporting in the present study. $\alpha$-amyrin (10.62\%) was identified as one of the major compounds followed by Globulol (7.02\%), phthalic acid mono-2-ethylhexyl ester (3.88\%), $n$-hexadecanoic acid (3.76\%), (-)-aromadendrene (3.56\%), (+)-aromadendrene (3.53\%),

Table 1

$\mathrm{IC}_{50}$ values of different parts of $M$. ferrea against human colon cancer cell line (HCT 116).

\begin{tabular}{llll}
\hline S. No & Part Used & Solvent & $\mathrm{IC}_{50} \mu \mathrm{g} / \mathrm{mL}$ \\
\hline 1 & Stem Bark & Methanol & $20.89 \pm 1.49$ \\
2 & Leaves & Methanol & $232.51 \pm 4.09$ \\
3 & Flowers & Methanol & $21.21 \pm 1.58$ \\
4 & Bark & n-Hexane & $18.56 \pm 0.513$ \\
5 & & Chloroform & $20.12 \pm 0.670$ \\
6 & & Ethyl acetate & $29.19 \pm 2.268$ \\
7 & & Methanol & $28.55 \pm 0.986$ \\
\hline
\end{tabular}

Values shown are in $\mu \mathrm{g} / \mathrm{mL}$ after $48 \mathrm{~h}$ of treatment with different parts of the plant $(n=3)$. (-)-aristolone (2.06\%) and 2,4-di-tert-butylphenol (1.69\%) (Fig. 1 ). MS-spectra of $\alpha$-amyrin identified in F-3 and standard $\alpha$-amyrin is shown in Supplementary Fig. S1.

In vitro antioxidant activities

Bioactive fraction showed weak antioxidant activity

F-3 showed weak free radical scavenging activity as compared with standard (ascorbic acid) in all the models (DPPH, ABTS and FRAP) employed in the present study (Table 2).

Bioactive fraction increased reactive oxygen species (ROS) levels in HCT 116 cells

Treatment with F-3 caused significant increase in ROS levels in HCT 116 cells compared to the untreated cells (0.5\% DMSO) in a dose-dependent fashion. The fluorescence intensities of ROS in F-3, $0.05 \% \mathrm{H}_{2} \mathrm{O}_{2}$ and $0.5 \%$ DMSO treated groups are shown in Fig. 2.

In vitro anticancer activities

Bioactive fraction induced toxicity in multiple human cancer cell lines Findings of the MTT cell viability study showed that F-3 was most active against HCT 116 cell line with an $\mathrm{IC}_{50}$ value of $14.79 \pm 1.25 \mu \mathrm{g} /$ $\mathrm{mL}$. The order of sensitivity (high to low) of cancer cell lines towards F-3 was HCT 116 $>$ MNK-74 $>$ PC $-3>$ T-47D $>$ MIA PaCa-2 $>$ HT-29 > PANC $-1>$ MCF-7 > Capan-1 respectively. CCD-18co, 3T3L1 and EA.hy926 were used as control cell lines to test the toxicity of F-3 towards normal cells, and to calculate selectivity index (SI) values. F-3 exerted relatively weak cytotoxic effects towards normal cells (Table 3 ). Based on the $\mathrm{IC}_{50}$ and SI values further testing was carried on HCT 116 cells using F-3 (Figs. 3 and 4).

Bioactive fraction damaged mitochondria and nuclei of HCT 116 cells

Significant decrease in mitochondrial outer membrane potential (MOMP) as indicated by profound reduction in red fluorescent signal was observed in HCT 116 cells treated with 7, 14 and $28 \mu \mathrm{g} /$ $\mathrm{mL}$ of F-3. The PCD index at 7,14 and $28 \mu \mathrm{g} / \mathrm{mL}$ of F-3 and $5 \mu \mathrm{g} / \mathrm{mL}$ of 5 -FU was $47.29 \pm 24.02 \%, 77.94 \pm 15.47 \%, 85.30 \pm 5.64 \%$ and $72.75 \pm 10.05 \%$ respectively, and was significantly greater compared to the control cells i.e., $0.5 \%$ DMSO in media $(16.75 \pm 2.07 \%)$.

Similarly, typical PCD features i.e., more brightly stained blue nuclei with kidney-shaped morphology and condensed chromatins were observed in the nuclei of F-3 and 5-FU treated HCT 116 cells in a dose-dependent manner. The PCD index in F-3 (7, 14 and $28 \mu \mathrm{g} / \mathrm{mL}$ ) and 5-FU treatment groups was $28.71 \pm 13.98 \%$,

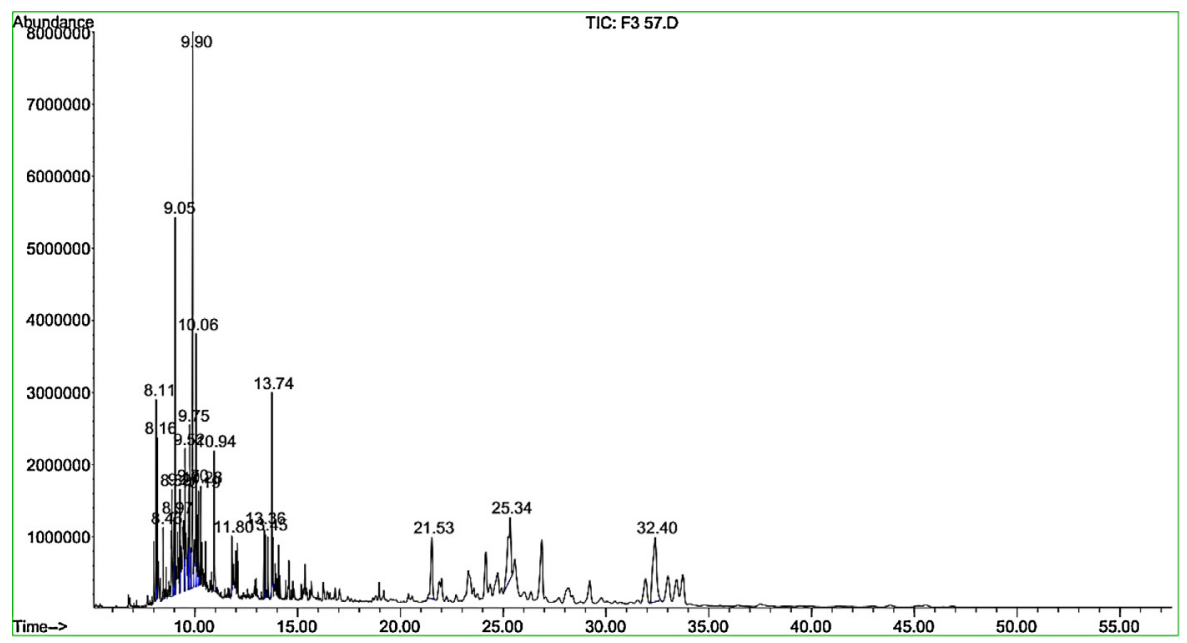

Fig. 1. GC-MS chromatogram of bioactive fraction (F-3) obtained from the stem bark extract. 
Table 2

Free radical scavenging activity of bioactive fraction (F-3).

\begin{tabular}{|c|c|c|c|c|}
\hline \multirow[t]{2}{*}{ S. No } & \multirow[t]{2}{*}{ Sample/Standard } & \multicolumn{3}{|c|}{ Antioxidant models } \\
\hline & & DPPH IC $50 \mu \mathrm{g} / \mathrm{mL}$ & ABTS IC $50 \mu \mathrm{g} / \mathrm{mL}$ & $\operatorname{FRAP}\left(\mu \mathrm{mol} \mathrm{Fe}{ }^{+2}\right.$ eq./mg extract \\
\hline 1 & Terpenes rich fraction (F-3) & $360.77 \pm 11.17$ & $182.96 \pm 25.58$ & $0.329 \pm 1.39$ \\
\hline 2 & Ascorbic acid & $3.83 \pm 0.03$ & $5.27 \pm 0.21$ & - \\
\hline
\end{tabular}

Values shown are in mean \pm SD of three independent experiments $(n=3)$

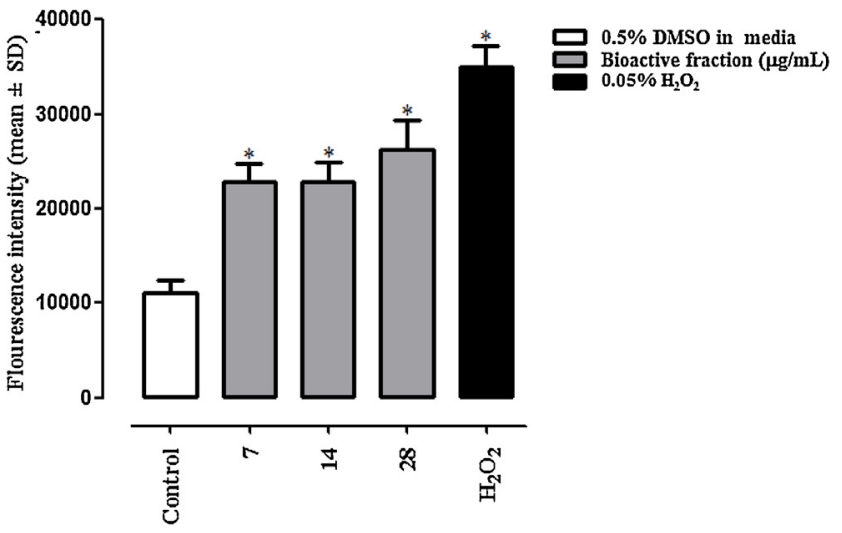

Fig. 2. Effect of terpenes rich-fraction (F-3) on reactive oxygen species levels in HCT 116 cells after $24 \mathrm{~h}$ of treatment. Significant increase in levels of ROS was observed in F-3 treated group compared to the control cells (0.5\% DMSO). $0.05 \% \mathrm{H}_{2} \mathrm{O}_{2}$ a wellknown inducer of ROS production was used as positive control. ${ }^{*}=p<0.001$.

Table 3

$\mathrm{IC}_{50}$ values of terpenes rich-fraction (F-3) against a panel of cancer and normal cell lines.

\begin{tabular}{llllll}
\hline S. No & Cell line & IC $_{50}$ value $(\mu \mathrm{g} / \mathrm{mL})$ & \multicolumn{3}{l}{ Selectivity Index $(\mathrm{SI})$} \\
\cline { 4 - 6 } & & & w.r.t & w.r.t & w.r.t \\
& & & EA.hy926 & CCD-18co & 3T3-L1 \\
\hline 1 & T-47D & $25.75 \pm 0.76$ & 1.77 & 2.43 & 2.03 \\
2 & MCF-7 & $43.57 \pm 0.30$ & 1.04 & 1.44 & 1.19 \\
3 & PC-3 & $20.78 \pm 1.06$ & 2.19 & 3.02 & 2.50 \\
4 & PANC-1 & $39.24 \pm 0.61$ & 1.16 & 1.59 & 1.32 \\
5 & MIA PaCa-2 & $32.97 \pm 1.03$ & 1.38 & 1.90 & 1.58 \\
6 & Capan-1 & $47.84 \pm 1.08$ & 0.95 & 1.31 & 1.08 \\
7 & HCT 116 & $14.79 \pm 1.25$ & 3.08 & 4.24 & 3.52 \\
8 & HT-29 & $35.79 \pm 1.32$ & 1.27 & 1.75 & 1.45 \\
9 & MKN-74 & $17.15 \pm 10.72$ & 2.66 & 3.65 & 3.03 \\
10 & EA.hy926 & $50.47 \pm 2.57$ & - & - & - \\
11 & CCD-18co & $62.76 \pm 1.76$ & - & - & - \\
12 & 3T3-L1 & $52.10 \pm 0.49$ & - & - & - \\
\hline
\end{tabular}

Values shown are mean \pm SD after $48 \mathrm{~h}$ of treatment with F-3. SI was calculated by comparing the $\mathrm{IC}_{50}$ values in normal and cancer cell line. $($ Where w.r.t = with respect to).

$43.86 \pm 11.15 \%, 66.48 \pm 15.53 \%$ and $79.25 \pm 8.52 \%$ respectively, and was significantly greater compared to the control cells $(7.19 \pm 1.09 \%)$.

Fluorescent staining studies using CCD-18co cells revealed that F-3 did not significantly damage the mitochondria and nuclei of normal colon fibroblast cells at the tested concentrations (Figs. 5 and 6).

Bioactive fraction altered the expression of multiple proteins involved in the programmed cell death cascade

Findings of human apoptosis protein profiler showed that F-3 at the dose of $14 \mu \mathrm{g} / \mathrm{mL}$ significantly altered the expression of multiple proteins (pro- and anti-apoptotic) in HCT 116 cells (Fig. 7). Relative fold change in the expression of Bcl2, Casp3, FasL, HSP60, livin, Survivin, TRAILR-1, TRAILR-2, TRAILR-3 and XIAP proteins was $-3.04 \pm 1.44, \quad 2.19 \pm 0.57, \quad 2.40 \pm 0.31, \quad-2.01 \pm 0.10, \quad 1.93 \pm 1.10$, $-3.02 \pm 0.14, \quad 3.36 \pm 0.04, \quad 9.25 \pm 0.63, \quad-2.47 \pm 0.03 \quad$ and $-1.95 \pm 0.09$ respectively. Fold change values with negative sign represent down-regulation in the activity.

Bioactive fraction down-regulated the expression of $N F-\kappa B$ and HIF-1 $\alpha$ transcription factors

Outcome of Cignal finder reporter array revealed that F-3 at the dose of $14 \mu \mathrm{g} / \mathrm{mL}$ significantly down-modulated the expression of $\mathrm{NF}-\kappa \mathrm{B}(0.47 \pm 0.14)$ and HIF- $1 \alpha(0.45 \pm 0.16)$ transcription factors in HCT 116 cells (Fig. 8). Fold change ratio values less than 1 represent down-regulation in activity.

$\alpha$-amyrin showed optimal binding affinities in silico docking studies

In silico protein interaction studies of $\alpha$-amyrin (marker compound of F-3) with selected molecular targets i.e., NF-кB and HIF- $1 \alpha$ showed optimal binding affinities compared to betulinic acid (used as standard), giving hint about multi-targeted nature of $\alpha$-amyrin (Table 4). The interaction of $\alpha$-amyrin and betulinic acid with selected protein are shown in Supplementary Figs. S2-S3.

\section{Discussion}

Colorectal cancer (CRC), a complex multistep phenomenon, is one of the three most common cancers worldwide. According to national cancer registry (NCR) report of Malaysia, CRC was the second most common cancer diagnosed during the year 2007 (Ariffin and Saleha, 2011; Asif et al., 2016b), which highlights the need to find new treatment strategies to manage this life threatening ailment. In the recent years extensive research has been conducted on natural products to find new drug moieties that can be used safely for the prevention and treatment of CRC (Miura et al., 2015). Present study describes the molecular mechanisms responsible for in vitro cytotoxic attributes of terpenes richfraction (F-3) towards human colon carcinoma HCT 116 cells. Among the crude extracts of various plant parts, SB extract with an IC $_{50}$ value of $20.89 \mu \mathrm{g} / \mathrm{mL}$ towards HCT 116 cells was selected following NCI criteria (Asif et al., 2016b). Subsequently, using bioactivity guided approach from the SB crude soxhlet extracts, non-polar ( $n$-Hex) extract and its terpenes rich-fraction (F-3) were selected for additional studies. Observations of current study are consistent with other studies where $n$-Hex extract from root bark of $M$. ferrea was shown to be more cytotoxic towards a panel of human cancer cell lines compared with other solvent extracts (Teh et al., 2013). Noteworthy, the current study reports for the first time the in vitro cytotoxic activity of $M$. ferrea stem bark against HCT 116, PC-3, PANC-1, Capan-1, MIA PaCa-2 and MKN-74 cell lines respectively whereas other studies reported the anticancer activities of blossoms, leaves, flowers, seeds and root bark extracts of M. ferrea (Adewale et al., 2012; Mahavorasirikul et al., 2010; Sukanya and Samart, 2012; Teh et al., 2011, 2013).

One of the most common obstacles in anticancer drug development is that the active agents induce toxicity in the normal body cells as well which leads to the appearance of side effects thus limiting their further use (Asif et al., 2016a). 

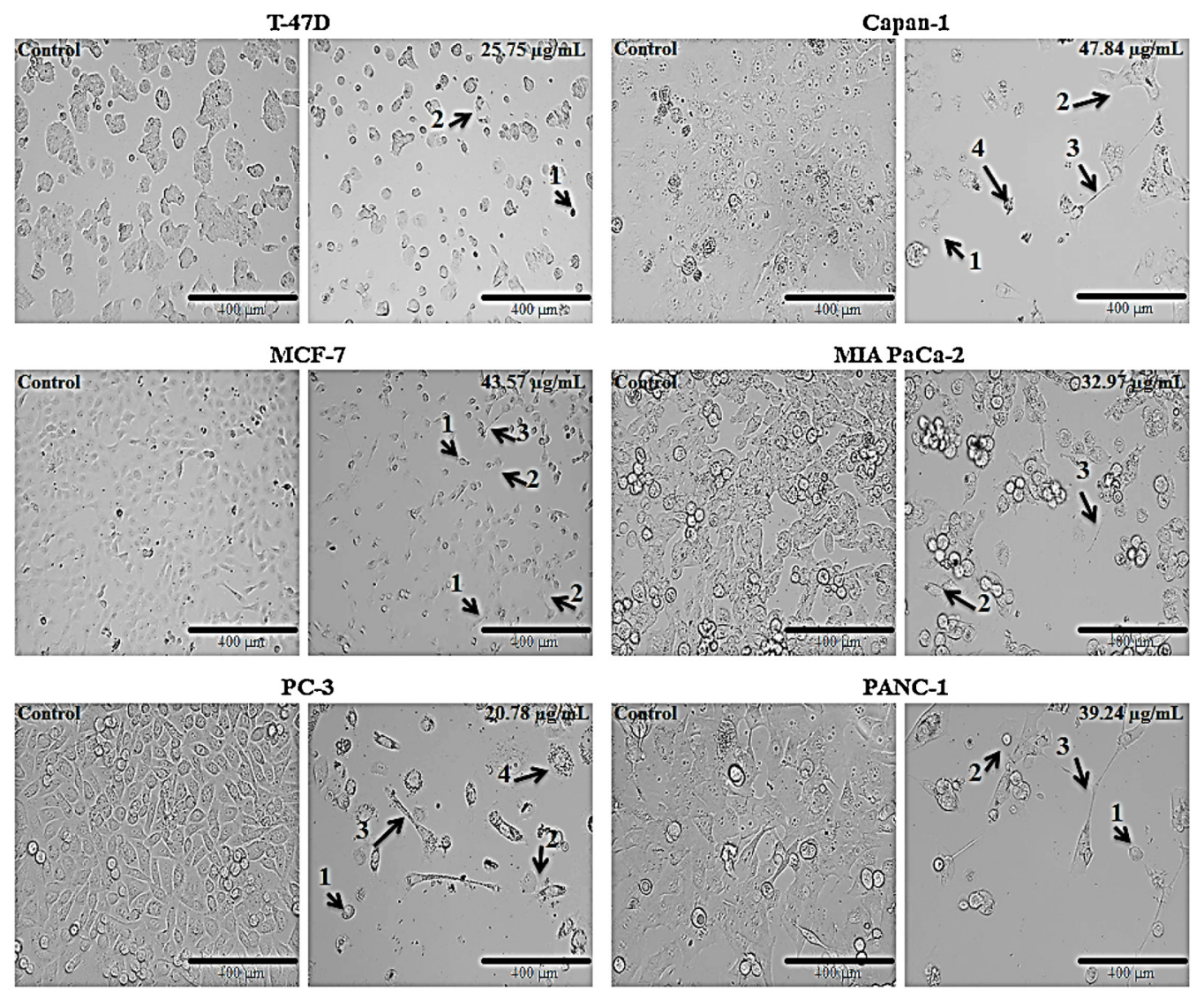

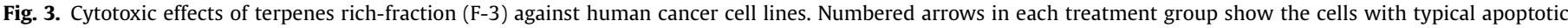

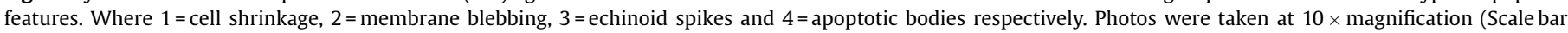
$400 \mu \mathrm{m})$.

Noteworthy, natural products have been reported to selectively kill the cancer cells with little or even no harmful effects towards the normal cells. Therefore, an extensive research is being conducted in the area of natural products to discover new agents having selective toxicity towards cancer cells. Studies have reported that SI value $\geq 3$ indicates good activity of test sample towards cancer cells, while $\mathrm{SI}<2$ indicates general toxicity of test samples (Machana et al., 2012). In the current study three normal cell lines i.e., CCD-18co, 3T3-L1, EA.hy926 from different origins were employed to study the cytotoxic nature (selective or non-selective) of phytochemicals present in F-3. Data obtained, showed that F-3 was highly selective towards HCT 116 cells with SI values of 4.24, 3.52 and 3.08 respectively. Second most responding cell line was MKN-74 with SI values of 3.65, 3.03 and 2.66 respectively. Finding of our study are in line with other research reports where natural products were shown to have selective cytotoxic effects towards cancer cells (Asif et al., 2016b; Hafidh et al., 2012).

GC-MS analysis of F-3 revealed that it was majorly comprised of different types of terpenes. $\alpha$-amyrin, a pentacyclic triterpenoid, was identified as one of the major compounds. Anticancer activities of terpenes including $\alpha$-amyrin, its derivatives and mixture of $\alpha$ - and $\beta$-amyrin against a variety of cancer cell lines has already been reported. This suggests that $\alpha$-amyrin and other terpenes constituents of F-3 are playing a major role towards its anticancer activity (Barros et al., 2011; Huang et al., 2012; Keawsaard et al., 2015; Salama et al., 2012).

Increased cellular proliferation and evasion of PCD is one of the most common features of CRC which help in the growth of malignant cells, tumor metastasis and generation of resistance against anticancer drugs. Therefore, it is highly desirable to induce
PCD in cancer cells in order to arrest these processes (Koff et al., 2015; Wong, 2011). In the present study cytological observations as well as fluorescent staining assays were employed to study the PCD-inducing effects of F-3. Typical characteristics of PCD i.e., cell shrinkage, membrane blebbing and formation of echinoid spikes were observed in the treated cells when observed under inverted light microscope (Figs. 3 and 4). However, more pronounced effects were in Capan-1, HCT 116, MCF-7, PANC-1 and PC-3 cells than rest of the cell lines tested in the current study. Results of the current study are in line with the findings of other research reports mentioning the appearance of similar kind of morphological features in the cancer cells treated with natural products (Asif et al., 2016b; Rahman et al., 2013). Interestingly, no apparent changes in the morphology of normal cells were observed when treated with F-3, thus giving a hint about selective PCD-inducing nature of bioactive constituents. In an attempt to study PCD features at subcellular level two cell organelle specific probes i.e., Hoechst 33258 (blue) and Rhodaamine 123 (red) were employed. Characteristic features were observed in both the assays suggesting that F-3 phytoconstituents target multiple cellular organelles in HCT 116 cells (Figs. 5 and 6). PCD-inducing activities of amyrin esters against HL-60 cells has already been reported which suggests that observed effects of F-3 might be due to its high $\alpha$-amyrin contents (Barros et al., 2011). However, further studies to isolate $\alpha$-amyrin from the SB and test this hypothesis are undergoing in our laboratory.

Cancer cells are regarded as metastable system. Owing to their fast proliferation rates these cells generate loads of reactive oxygen species (ROS) which is usually balanced by high intracellular antioxidants. Therefore, agents which can either reduce the 

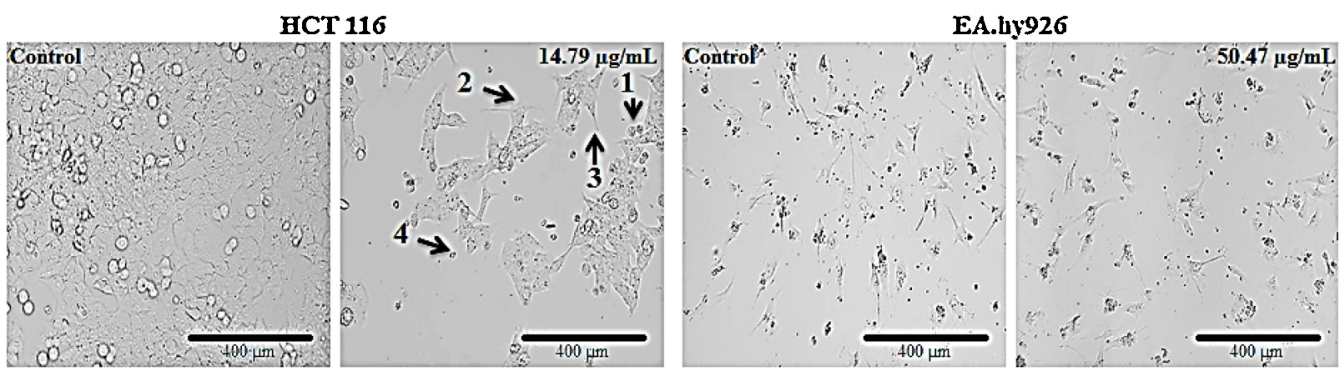

HT-29
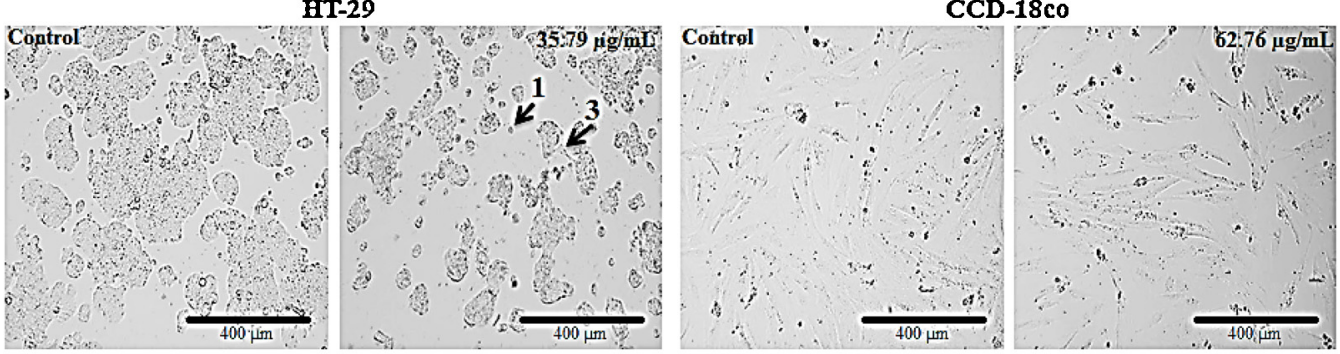

MKKN-74

3T3-L1-1
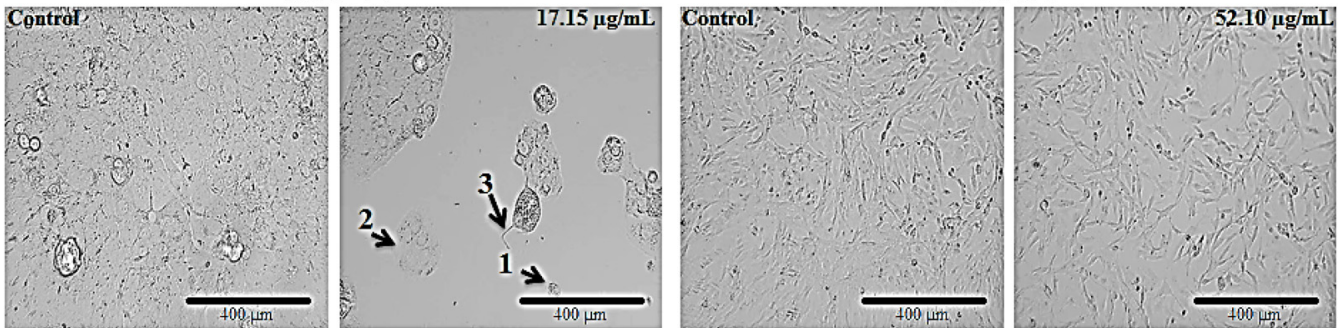

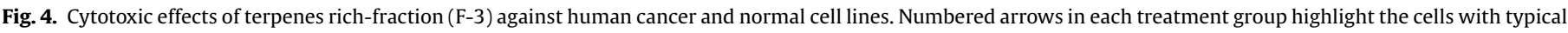

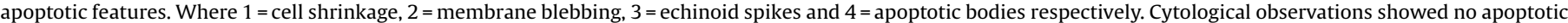

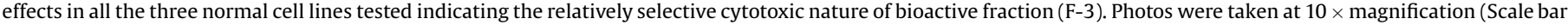
$400 \mu \mathrm{m})$.
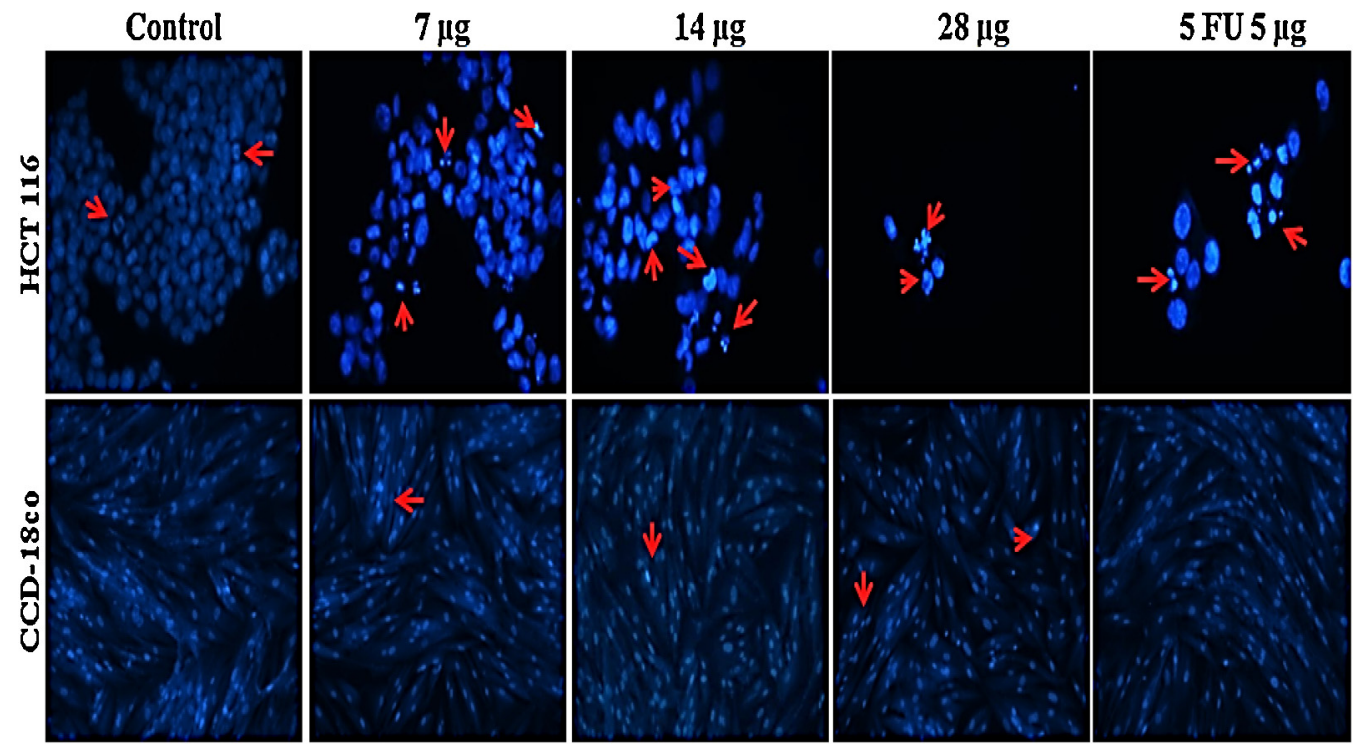

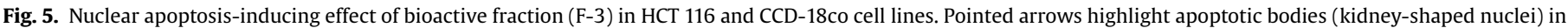

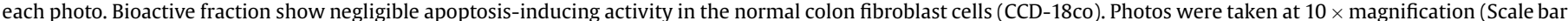
$400 \mu \mathrm{m})$.

intracellular antioxidant levels or slightly increase the ROS production in cancer cells may result in lethal damage and death in cancer cells. In contrast, normal cells usually have lower basal ROS levels and can tolerate this oxidative insults to much greater extend and have stronger antioxidant capacities (Sun et al., 2013). Finding of current study showed dose-dependent increase in ROS levels in HCT 116 cells compared to 0.5\% DMSO treated cells pointing towards ROS-mediated cell death as one of the main 

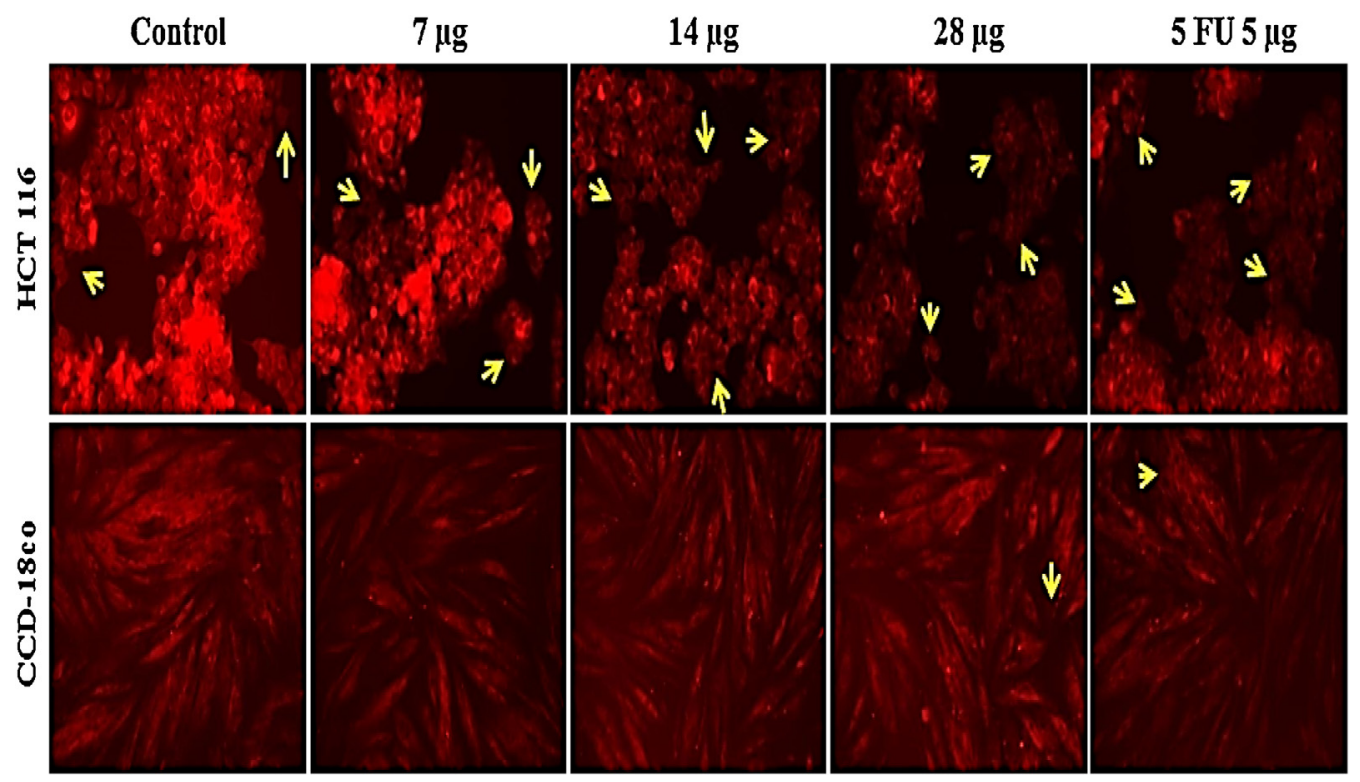

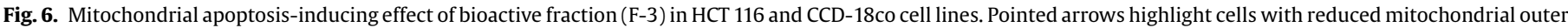

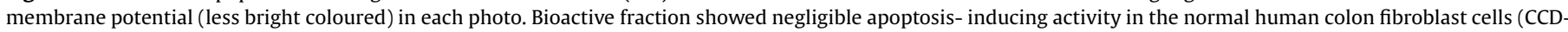
$18 \mathrm{co}$ ). Photos were taken at $10 \times$ magnification (Scale bar $400 \mu \mathrm{m}$ ).

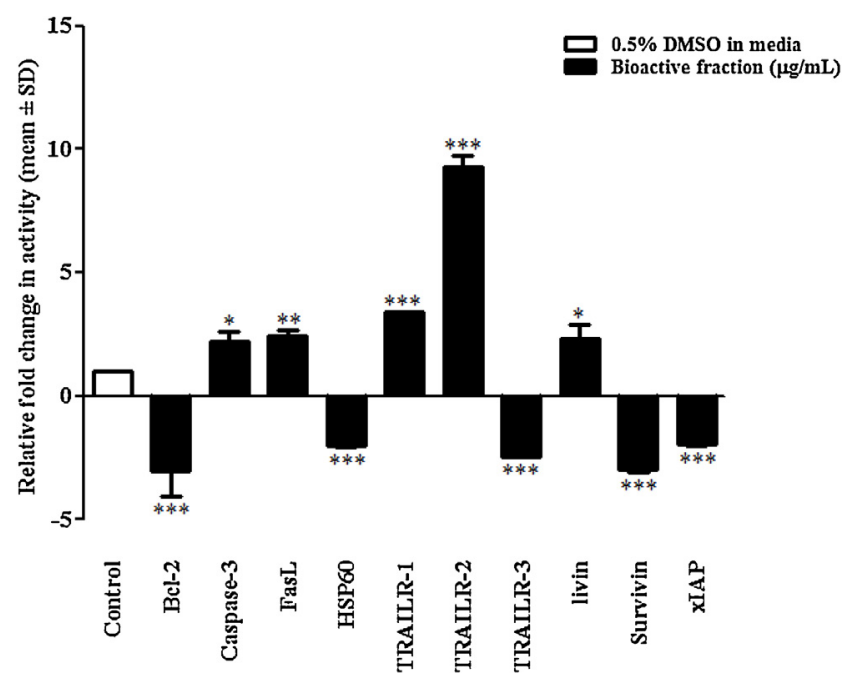

Fig. 7. Effect of bioactive fraction (F-3) 3 on the expression pattern of proteins involved in programmed cell death cascade. ${ }^{*}=p<0.05,{ }^{* *}=p<0.01$ and ${ }^{* * *}=p$ $<0.001$. Statistical analysis was performed by assuming the value of each protein in control cells as 1 .

mechanisms responsible for the observed cytotoxic activity. Results of present study are consistent with other research reports where selective increase in ROS generation in cancer cells was observed after treatment with natural products. Similarly, 5Fluorouracil, a standard drug to treat CRC, has also been reported to induce cell death through generation of ROS (Fu et al., 2014; Wen et al., 2002; Xu et al., 2014; Zou et al., 2015). After establishing the ROS promoting role of $\mathrm{F}-3$, we further confirmed the results by a series of in vitro antioxidant assays i.e., DPPH, ABTS and FRAP, and findings of the study revealed that F-3 phytoconstituents has weak activity in all the models employed.

CRC is known to progress from adenoma to carcinoma through deformities in HIF- $1 \alpha$ and NF-KB signalling pathways and their downstream proteins which collectively contribute towards increased tumor cell proliferation, angiogenesis, invasion, metastasis and resistance against chemotherapy-induced PCD in CRC cell lines (Aggarwal et al., 2013). Therefore, one of the most rational approaches to arrest tumorigenesis is to control initiation, promotion and progression steps as well as associated cell signalling pathways (Asif et al., 2016a; Koehler et al., 2014). Moreover, an inverse relationship between intracellular ROS levels and expression of $\mathrm{HIF}-1 \alpha, \mathrm{NF}-\mathrm{\kappa} B$, survivin and $\mathrm{Bcl}-2$ family proteins has also been established by numerous studies (Asif et al., 2016b; Hassanzadeh, 2011; Ioannou et al., 2015; Li et al., 2004; Sakamoto et al., 2009). Data of human transcription factor reporter array revealed that treatment with F-3 resulted in significant down-regulation in the activity of two major oncogenic pathways (HIF- $1 \alpha$ and NF-KB) in HCT 116 cells and is also supported by the outcomes of in silico modelling studies. Further extending the study, effect of this down-regulation on the

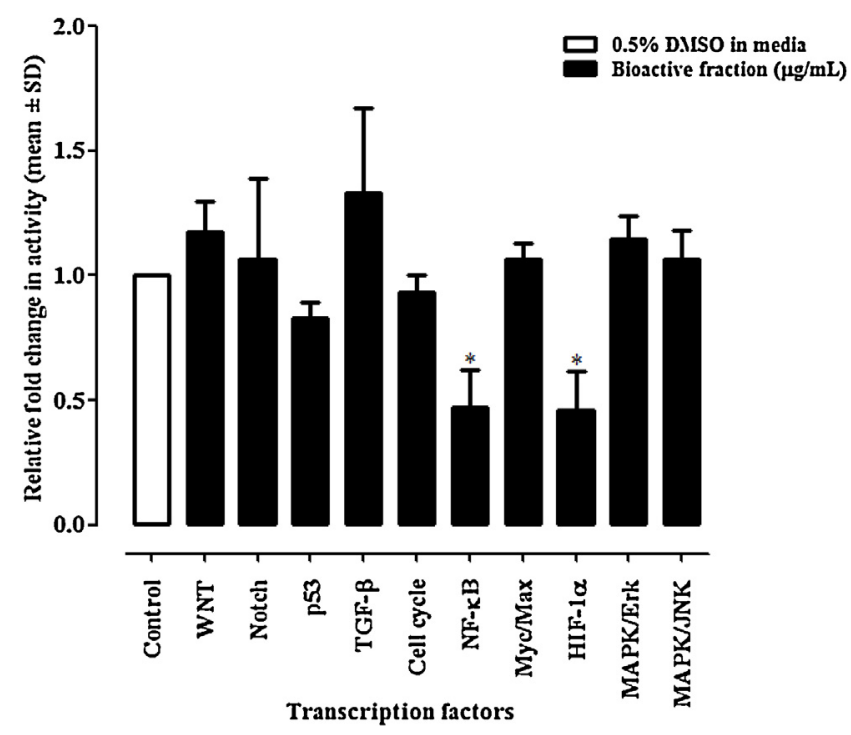

Fig. 8. Effect of bioactive fraction (F-3) 3 on the expression pattern of transcription factors for 10 major oncogenic pathways. Significant $\left({ }^{*}=p<0.05\right)$ down-regulation in the expression of two oncogenic pathways was observed in HCT 116 cells treated with F-3. Statistical analysis was performed by assuming the value of each protein in control cells as 1 . 
Table 4

Molecular interaction data of $\alpha$-amyrin and betulinic acid against selected targets.

\begin{tabular}{|c|c|c|c|c|c|c|}
\hline \multirow[t]{2}{*}{ S. No } & \multirow{2}{*}{$\begin{array}{l}\text { Target } \\
\text { (PDB code) }\end{array}$} & \multirow[t]{2}{*}{ Ligand } & \multirow{2}{*}{$\begin{array}{l}\text { Binding energy } \\
\text { (Kcal/mol) }\end{array}$} & \multicolumn{2}{|c|}{ Hydrogen bond interactions } & \multirow[t]{2}{*}{ Residue interactions } \\
\hline & & & & Interacting amino acids & H-bond length $(\AA)$ & \\
\hline 1 & NF- $\mathrm{KB}(1 \mathrm{NFI})$ & $\alpha$-amyrin & -8.3 & ARG236-GLU225 & 2.99 & $\begin{array}{l}\text { LYS28, GLU49, ARG50, SER51, THR5, GLU222, } \\
\text { ASP223, ILE224,GLU225, VAL226, ARG236, } \\
\text { GLY237, SER238, PHE239, GLN241, PRO275, } \\
\text { GLY259, ARG260, PRO261, UNK0 }\end{array}$ \\
\hline \multirow[t]{6}{*}{2} & $\mathrm{HIF}-1 \alpha(2 \mathrm{CGO})$ & & -8.6 & ASP104-PRO235 & 2.81 & SER91, TYR93, TYR102, TYR103, ASP104, GLU105, \\
\hline & & & & LYS106-ASP104 & 2.99 & LYS106, ARG120, GLN147, LEU186, \\
\hline & & & & ARG120-GU105 & 3.08 & THR196, HIS199, ASP201, PRO235, CYS236, \\
\hline & & & & GLN239-TYR102 & 2.68 & ASP237, ARG238, GLN239, UNK0 \\
\hline & & & & ASP1539-ASP1539 & 2.91 & \\
\hline & & & & PHE1591-SER1590 & 3.18 & \\
\hline \multirow[t]{3}{*}{3} & NF- $\kappa B(1 N F I)$ & Betulinic acid & -7.2 & SER316-ILE312 & 2.79 & ILE312, SER316, PRO317, PHE318, LEU70, THR71, \\
\hline & & & & SER316-SER316 & 2.90 & PHE77, PHE103, UNK0 \\
\hline & & & & THR71-LEU70 & 2.52 & \\
\hline \multirow[t]{4}{*}{4} & HIF- $1 \alpha(2 \mathrm{CGO})$ & & -8.5 & SER91-GLU122 & 2.93 & SER91, TYR93, TYR102, TYR103, ASP104, LYS106, \\
\hline & & & & SER91-GLN148 & 3.10 & ARG120, GLN147, GLN148, THR149, LEU186, \\
\hline & & & & ASP104-PRO235 & 2.81 & THR196, HIS199, ASP201, PRO235, CYS236, \\
\hline & & & & GLN239-TYR102 & 2.68 & ASP237, ARG238, GLN239, HIS279, TRP296, UNK0 \\
\hline
\end{tabular}

expression of multiple proteins involved in the PCD cascade was studied using a human apoptosis proteome profiler. F-3 upregulated the expression of two cell surface death receptors (TRAILR-1 and TRAILR-2) with concurrent down-regulation of Bcl2, HSP60, survivin, TRAILR-3 and XIAP proteins in HCT 116 cells. Collectively, these changes resulted in enhancement of cell PCD signal generated by F-3 phytoconstituents. This led to the activation of executioner caspases (Casp3) which then initiated a sequence of events leading to the disintegration of cellular and sub-cellular components of colon cancer cells as observed in light microscopic and fluorescent staining assays. Findings of current study are supported by other research reports where modulation of activity of multiple cell signalling pathways and their corresponding proteins by natural products suppressed proliferation and induced PCD in CRC cells (Huang et al., 2012; Wang et al., 2013; Pandurangan and Esa, 2014; Kunnumakkara et al., 2008; Khan et al., 2015).

\section{Conclusion}

Overall, results of current study demonstrate that selective cytotoxic effect of terpenes rich-fraction (F-3) towards human colon cancer cells are mainly because of ROS dependent downmodulation of HIF- $1 \alpha$, and NF- $\mathrm{KB}$ cell signalling pathways and their downstream cell death proteins. Further studies to isolate active compounds in bulk amount and explore their in vivo antitumor effects are ongoing in our laboratory.

\section{Conflict of interest}

The authors declare no conflict of interest in the present work.

\section{Acknowledgment}

The authors would like to acknowledge the Institute of Postgraduate Studies at the Universiti Sains Malaysia for supporting this project through USM Fellowship and USM-TWAS Fellowship.

\section{Appendix A. Supplementary data}

Supplementary data associated with this article can be found, in the online version, at http://dx.doi.org/10.1016/j.jab.2016.10.003.

\section{References}

Abdel-Hameed, E.S.S., Salih, A.B., Mohamed, M.S., Mortada, M.E.S., Eman, A.E.W. 2012. Phytochemical studies and evaluation of antioxidant anticancer and antimicrobial properties of Conocarpus erectus L. growing in Taif, Saudi Arabia. Eur. J. Med. Plants 2, 93-112.

Adewale, A.I., Mirghani, M.E.S., Muyibi, S.A., Daoud, J.I., Abimbola, M.M., 2012. AntiBacterial and cytotoxicity properties of the leaves extract of nahar (Mesua ferrea) plant. Adv. Nat. Appl. Sci. 6, 583-587.

Aggarwal, B., Prasad, S., Sung, B., Krishnan, S., Guha, S., 2013. Prevention and treatment of colorectal cancer by natural agents from mother nature. Curr. Colorectal. Cancer. Rep. 9, 37-56.

Amin, A., Gali-Muhtasib, H., Ocker, M., Schneider-Stock, R., 2009. Overview of major classes of plant-derived anticancer drugs. Intern. J. Biomed. Sci. 11, 1-11.

Anighoro, A., Bajorath, J., Rastelli, G., 2014. Polypharmacology: challenges and opportunities in drug discovery. J. Med. Chem. 57, 7874-7887.

Ariffin, O.Z., Saleha, I.N., 2011. NCR Report 2007. Ministry of Health, Malaysia.

Asif, M., Jabeen, Q., Majid, A.A., Atif, M., 2015. Diuretic activity of aqueous extract of Nigella sativa in albino rats. Acta Pol. Pharm. 72, 129-135.

Asif, M., Yehya, A.H.S., Al-Mansoub, M.A., Revadigar, V., Ezzat, M.O., Ahamed, M.B.K., Oon, C.E., Murugaiyah, V., Majid, A.S.A., Majid, A.M.S.A., 2016a. Anticancer attributes of Illicium verum essential oils against colon cancer. S. Afr. J. Bot. 103, $156-161$.

Asif, M., Shafaei, A., Jafari, S.F., Mohamed, S.b.K., Ezzat, M.O., Majid, A.S.A., Oon, C.E., Petersen, S.H., Kono, K., Majid, A.M.S.A., 2016b. Isoledene from Mesua ferrea oleo-gum resin induces apoptosis in HCT 116 cells through ROS-mediated modulation of multiple proteins in the apoptotic pathways: a mechanistic study. Toxicol. Lett. 257, 84-96.

Asif, M., Iqbal, M.A., Hussein, M.A., Oon, C.E., Haque, R.A., Ahamed, M.B.K., Majid, A.S. A., Majid, A.M.S.A., 2016c. Human colon cancer targeted pro-apoptotic: antimetastatic and cytostatic effects of binuclear Silver(I)-N-Heterocyclic carbene (NHC) complexes. Eur. J. Med. Chem. 108, 177-187.

Barros, F., Bandeira, P., Lima, D., Meira, A., Farias, S.d., Albuquerque, M., Santos, H.d., Lemos, T., Morais, M.d., Costa-Lotufo, L., Cdo, O.P., 2011. Amyrin esters induce cell death by apoptosis in HL-60 leukemia cells. Bioorg. Med. Chem. 19, 12681276.

Fu, Y., Yang, G., Zhu, F., Peng, C., Li, W., Li, H., Kim, H.G., Bode, A., Dong, Z.D.Z., 2014. Antioxidants decrease the apoptotic effect of 5-FU in colon cancer by regulating Src-dependent caspase-7 phosphorylation. Cell. Death. Dis. 5, e983.

Fulda, S., 2008. Betulinic acid for cancer treatment and prevention. Int. J. Mol. Sci. 9, 1096-1107.

Hafidh, R.R., Abdulamir, A.S., Bakar, F.A., Jalilian, F.A., Abas, F, Sekawi, Z, 2012. Novel molecular, cytotoxical, and immunological study on promising and selective anticancer activity of Mung bean sprouts. BMC. Complement. Altern. Med. 12, 208.

Hassanzadeh, P., 2011. Colorectal cancer and NF-кB signaling pathway. Gastroenterol. Hepatol. Bed Bench 4, 127-132. 
Hildeman, D.A., Mitchell, T., Aronow, B., Wojciechowski, S., Kappler, J., Marrack, P. 2003. Control of Bcl-2 expression by reactive oxygen species. PNAS 100, 1503515040.

Huang, M., Lu, J., Huang, M., Bao, J., Chen, X., Wang, Y., 2012. Terpenoids: natural products for cancer therapy. Expert. Opin. Investig. Drugs 21, 1801-1818.

Ioannou, M., Paraskeva, E., Baxevanidou, K., Simos, G., Papamichali, R., Papacharalambous, C., Samara, M., Koukoulis, G., 2015. HIF-1 $\alpha$ in colorectal carcinoma: review of the literature. J. BUON 20, 680-689.

Jia, G., Wang, Q., Wang, R., Deng, D., Xue, L., Shao, N., Zhang, Y., Xia, X., Zhi, F., Yang, Y., 2015. Tubeimoside-1 induces glioma apoptosis through regulation of Bax/Bcl-2 and the ROS/Cytochrome C/Caspase-3 pathway. Oncol. Targets Ther. 8, 303-311.

Juan, M.E., Wenzel, U., Daniel, H., Planas, J.M., 2008. Resveratrol induces apoptosis through ROS-Dependent mitochondria pathway in HT-29 human colorectal carcinoma cells. J. Agric. Food. Chem. 56, 4813-4818.

Keawsa-ard, S., Liawruangrath, B., Kongtaweelert, S., 2015. Bioactive compounds from Mesua ferrea stems. Chiang. Mai. J. Sci. 42, 185-195.

Khan, M., Maryam, A., Qazi, J.I., Ma, T., 2015. Targeting apoptosis and multiple signaling pathways with icariside II in cancer cells. Int. J. Biol. Sci. 11, 1100-1112.

Koehler, B.C., Jäger, D., Schulze-Bergkamen, H., 2014. Targeting cell death signaling in colorectal cancer: current strategies and future perspectives. World J. Gastroenterol. 20, 1923-1934.

Koff, J.L., Ramachandiran, S., Bernal-Mizrachi, L., 2015. A time to kill: targeting apoptosis in cancer. Int. J. Mol. Sci. 16, 2942-2955.

Kunnumakkara, A.B., Anand, P., Aggarwal, B.B., 2008. Curcumin inhibits proliferation, invasion, angiogenesis and metastasis of different cancers through interaction with multiple cell signaling proteins. Cancer Lett. 269, 199_ 225.

Li, D., Ueta, E., Yamamoto, T.K.T., Osaki, T., 2004. Reactive oxygen species (ROS) control the expression of Bcl-2 family proteins by regulating their phosphorylation and ubiquitination. Cancer Sci. 95, 644-650.

Lu, J.J., Pan, W., Hu, Y.J., Wang, Y.T., 2012. Multi-target drugs: the trend of drug research and development. PLoS One 7, e40262.

Machana, S., Weerapreeyakul, N., Barusrux, S., 2012. Anticancer effect of the extracts from Polyalthia evecta against human hepatoma cell line (HepG2). Asian Pac. J. Trop. Biomed. 2, 368-374.

Mahavorasirikul, W., Viyanant, V., Chaijaroenkul, W., Itharat, A., Na-Bangchang, K., 2010. Cytotoxic activity of Thai medicinal plants against human cholangiocarcinoma, laryngeal and hepatocarcinoma cells in vitro. BMC Complement. Altern. Med. 28, 10-55.

Miura, K., Satoh, M., Kinouchi, M., Yamamoto, K., Hasegawa, Y., Kakugawa, Y., Kawai, M., Uchimi, K., Aizawa, H., Ohnuma, S., Kajiwara, T., Sakurai, H., Fujiya, T., 2015. The use of natural products in colorectal cancer drug discovery. Expert Opin. Drug Discov. 10, 411-426.

Pandurangan, A.K., Esa, N.M., 2014. Luteolin, a bioflavonoid inhibits colorectal cancer through modulation of multiple signaling pathways: a review. Asian Pac. J. Cancer Prev. 15, 5501-5508.

Prasad, S., Yadav, V.R., Kannappan, R., Aggarwal, B.B., 2011. Ursolic acid, a pentacyclin triterpene, potentiates TRAIL-induced apoptosis through p53-independent up- regulation of death receptors: evidence for the role of reactive oxygen species and JNK. J. Biol. Chem. 286, 5546-5557.

Rahman, S.N.S.A., Wahab, N.A., Malek, S.N.A., 2013. In vitro morphological assessment of apoptosis induced by antiproliferative constituents from the rhizomes of curcuma zedoaria. Evid-Based Complement. Altern. Med. 2013 doi: http://dx.doi.org/10.1155/2013/257108.

Sakamoto, K., Maeda, S., Hikiba, Y., Nakagawa, H., Hayakawa, Y., Shibata, W., Yanai, A., Ogura, K., Omata, M., 2009. Constitutive NF-кB activation in colorectal carcinoma plays a key role in angiogenesis, promoting tumor growth. Clin. Cancer Res. 15, 2248-2258.

Salama, M., Kandil, Z., Islam, W., 2012. Cytotoxic compounds from the leaves of Gaillardia aristata Pursh growing in Egypt. Nat. Prod. Res. 26, 2057-2062.

Sukanya, K., Samart, K., 2012. Antioxidant, antibacterial, anticancer activities and chemical constituents of the essential oil from Mesua ferrea leaves. Chiang. Mai. J. Sci. 39, 455-463.

Sun, X., Ai, M., Wang, Y., Shen, S., Gu, Y., Jin, Y., Zhou, Z., Long, Y., Yu, Q., 2013. Selective induction of tumor cell apoptosis by a novel P450-mediated reactive oxygen species (ROS) inducer methyl 3-(4-Nitrophenyl) propiolate. J. Biol. Chem. 288, 8826-8837.

Tan, W., Lu, J., Huang, M., Li, Y., Chen, M., Wu, G., Gong, J., Zhong, Z., Xu, Z., Dang, Y., Guo, J., Chen, X., Wang, Y., 2011. Anti-cancer natural products isolated from chinese medicinal herbs. Chin. Med. 6, 27. doi:http://dx.doi.org/10.1186/17498546-6-27.

Teh, S.S., Ee, G.C.L., Rahmani, M., Taufiq-Yap, Y.H., Go, R., Mah, S.H., 2011. Pyranoxanthones from Mesua ferrea. Molecules 16, 5647-5654.

Teh, S.S., Ee, G., Mah, S., Yong, Y., Lim, Y., Rahmani, M., Ahmad, Z., 2013. In vitro cytotoxic, antioxidant, and antimicrobial activities of Mesua beccariana (Baill.) Kosterm., Mesua ferrea Linn., and Mesua congestiflora extracts. Biomed. Res. Int. 2013 doi:http://dx.doi.org/10.1155/2013/517072.

Trott, O., Olson, A.J., 2010. AutoDock Vina: improving the speed and accuracy of docking with a new scoring function, efficient optimization and multithreading. J. Comput. Chem. 31, 455-461.

Wang, J., Liu, L., Qiu, H., Zhang, X., Guo, W., Chen, W., Tian, Y., Fu, L., Shi, D., Cheng, J., Huang, W., Deng, W., 2013. Ursolic acid simultaneously targets multiple signaling pathways to suppress proliferation and induce apoptosis in colon cancer cells. PLoS One 8, e63872.

Wen, J., You, K.R., Lee, S.Y., Song, C.H., Kim, D.G., 2002. Oxidative stress-mediated apoptosis. The anticancer effect of the sesquiterpene lactone parthenolide. J. Biol. Chem. 277, 38954-38964.

Wong, R., 2011. Apoptosis in cancer: from pathogenesis to treatment. J. Exp. Clin. Cancer Res. 30, 87. doi:http://dx.doi.org/10.1186/1756-9966-30-87.

Xu, T., Pang, Q., Zhou, D., Zhang, A., Luo, S., Wang, Y., Yan, X., 2014. Proteomic investigation into betulinic acid-induced apoptosis of human cervical cancer HeLa cells. PLoS One 9, e105768.

Zou, P., Zhang, J., Xia, Y., Kanchana, K., Guo, G., Chen, W., Huang, Y., Wang, Z., Yang, S., Liang, G., 2015. ROS generation mediates the anti-cancer effects of WZ35 via activating JNK and ER stress apoptotic pathways in gastric cancer. Oncotarget 6, 5860-5876. 